\title{
Identifikasi Bakteri Escherichia coli dan Salmonella sp. Pada Produk Beku Perikanan di Balai Karantina Ikan, Pengendalian Mutu, dan Keamanan Hasil Perikanan Surabaya II, Jawa Timur
}

\section{Identification Bacteri Escherichia coli and Salmonella sp. on Frozen Fishery Products at Balai Karantina Ikan, Pengendalian Mutu, dan Keamanan Hasil Perikanan Surabaya II, Jawa Timur}

\author{
Santika Dwi Christanti ${ }^{1 *}$, Muhammad Hanif Azhar ${ }^{2}$ \\ ${ }^{1}$ Program studi Akuakultur, Fakultas Perikanan dan Kelautan, PSDKU Universitas Airlangga di \\ Banyuwangi. \\ ${ }^{2}$ Depertemen Manajemen Kesehatan Ikan dan Akuakultur, Fakultas Perikanan dan Kelautan, \\ Universitas Airlangga \\ *Email: santika.dwi.christanti-2016@fpk.unair.ac.id
}

\begin{abstract}
Abstrak
Produk perikanan beku merupakan jenis komoditi dengan tingkat pengembangan yang beragam, baik dalam bentuk utuh maupun dalam bentuk potongan. Produk perikanan merupakan bahan pangan yang sangat mudah mengalami kontaminasi mikroba patogen sehingga dapat menyebabkan keracunan pangan serta menimbulkan wabah penyakit pada konsumen. Penelitian ini bertujuan untuk mengetahui berbagai jenis bakteri patogen yang mengkontaminasi produk beku perikanan. Produk beku perikanan yang diteliti berasal dari golongan tuna, makerel, moluska dan crustacea. Pemeriksaan bakteri Escherichia coli menggunakan metode ISO 16649-3:2015 dan bakteri Salmonella sp. menggunakan metode ISO 6579:2002. Hasil pengujian yang telah dilakukan dapat diketahui bahwa produk beku perikanan ada yang positif terkontaminasi dan negatif terkontaminasi Escherichia coli dan Salmonella sp.
\end{abstract}

Keyword : Teknik identifikasi bakteri, Escherichia coli, Salmonella sp.

\begin{abstract}
Frozen fishery products are a type of commodity with a diverse level of development, both in whole form and in the form of pieces. Fishery products is a food that is very easy to experience pathogenic microbial contamination that can cause food poisoning and cause disease outbreak in consumers. The purpose of this research to knowing the various types of pathogenic bacteria that can contaminate frozen fisheries. Fishery products that are researched are derived from the tuna, mackerel, mollusca and crustacean. The examination of Escherichia coli bacteria using the ISO 16649-3: 2015 method and Salmonella sp. using the ISO 6579: 2002 method. The results of tests that could determine that frozen fisheries products are positively contaminated or not contaminated with Escherichia coli and Salmonella sp.
\end{abstract}

Keyword : Bacteria identification technique, Escherichia coli, Salmonella sp. 


\section{PENDAHULUAN}

Ikan merupakan jenis bahan pangan yang mudah mengalami kerusakan biologis serta rentan dengan cemaran mikroba (Ma'ruf, 2017). Aktifitas mikroorganisme maupun aktivitas enzim yang terdapat dalam tubuh ikan dapat mengakibatkan proses pembusukan pada ikan. Jumlah mikroorganisme yang terdapat dalam bahan pangan dapat mempengaruhi cepat lambatnya kerusakan suatu bahan pangan. Proses pembusukan pada ikan dapat menghambat pemasaran produk perikanan, sehingga tidak jarang mengakibatkan kerugian besar saat produksi ikan melimpah (Hossain et al., 2015).

Proses karantina ikan sangat penting dilakukan untuk menjaga keamanan pangan serta mencegah timbulnya penyakit pada manusia akibat mengkonsumsi ikan maupun berbagai macam hasil olahan dari produk perikanan (Balai Karantina Ikan, 2011).

Keamanan pangan saat ini diperhatikan oleh masyarakat internasional karena kualitasnya yang semakin menurun. Salah satu keamanan pangan yang diperhatikan yaitu pada sektor perikanan. Hal tersebut dikarena pada sektor perikanan baik ekspor maupun impor terus mengalami peningkatan, sehingga perlu adanya persyaratan untuk mempertahankan mutu dari produk perikanan dengan standar yang tinggi pada bahan pangan khususnya pada sektor perikanan. (Garcia and Andrew, 2010).

Salah satu cara untuk mempertahankan mutu dari produk perikanan yaitu dengan melakukan pengujian pada produk perikanan. Hal tersebut penting dilakukan untuk mengawasi kualitas produk perikanan sehingga dapat memberikan jaminan keamanan pangan bagi konsumen/masyarakat (FAO, 2014).

Berdasarkan permasalahan diatas maka perlu diketahui berbagai jenis bakteri patogen yang dapat mengkontaminasi produk beku perikanan.

\section{METODE PENELITIAN}

\section{Waktu dan Tempat}

Penelitian ini dilaksanakan di Balai Karantina Ikan, Pengendalian Mutu dan Keamanan Hasil Perikanan Surabaya II selama 40 hari dari bulan 
Desember sampai Januari. Metode yang digunakan untuk permeriksaan bakteri yaitu metode ISO 166493:2015 dan metode ISO 6579:2002.

\section{Alat dan Bahan}

Peralatan yang digunakan dalam penelitian yaitu Autoclave, oven, cawan petri, tabung reaksi, bunsen, ose loop, mikropipet, inkubator, laminary air flow, timbangan digital, Erlenmeyer, Hot plate, Magic stirrer, Masker dan hand glove.

Bahan umum yang digunakan pada saat penelitian yaitu alkohol $70 \%$ dan akuades. Adapun media tidak selektif yang digunakan pada saat penelitian untuk uji bakteri Escherichia coli yaitu Butterfield's Phosphate Buffered dan Mineral Modified Glutamate Medium, sedangkan untuk uji bakteri Salmonella sp. yaitu Buffered Pepton Water, Rappaport-Vassiliadis, Muller-Kauffmann tetrathionatenovobiocin broth. Media selektif yang digunakan pada saat penilitian untuk uji bakteri Escherichia coli yaitu Tryptone Bile Glucoronide Agar, sedangkan untuk uji bakteri Salmonella sp. yaitu Xylose Lysine Desoxycholate.
Media yang digunakan untutk mengkonfirmasi hasil uji yaitu Triple Sugar Iron Agar, Lysine Iron Agar, Simmon's Citrat, Methyl Red Voges Proskauer, Urea agar, Laktosa, Sukrosa, Glukosa, Dulcitol dan Tryptone Borth.

\section{Prosedur Kerja}

\section{Proses Sterilisasi}

Sterilisasi basah dilakukan dengan menggunakan autoclave dengan suhu $121{ }^{\circ} \mathrm{C}$ dan tekanan 1 ATM selama 15 menit. Sterilisasi kering dilakukan dengan menggunakan oven dengan suhu 170 ${ }^{\circ} \mathrm{C}-180{ }^{\circ} \mathrm{C}$ selama \pm 1 jam.

\section{Persiapan media Media}

Media yang digunakan untuk pengujian bakteri dibagi menjadi tiga yaitu media cair, media semi padat dan media padat. Media cair yang digunakan dalam penelitian ini yaitu Butterfield's Phosphate Buffered, Tryptone Borth, Muller-Kauffmann tetrathionate-novobiocin broth, Buffered Pepton Water, Methyl Red Voges Proskauer, laktosa, sukrosa, glukosa dan dulcitol. Adapun media semi padat yang digunakan yaitu Sulfide Indole Motility, RappaportVassiliadis dan Lysine Iron Agar. 
Media padat yang digunakan yaitu Tryptone Bile Glucoronide Agar, Xylose Lysine Desoxycholate, Triple Sugar Iron Agar, Lysine Iron Agar, Simmon's Citrat dan Urea agar.

\section{Preparasi Sampel Produk Beku Perikanan}

Sampel produk beku perikanan yang digunakan dipotong menjadi kecil dengan ukuran $\pm 5 \mathrm{~cm}$ dan dimasukkan ke dalam plastik steril. Setelah itu, sampel ditimbang menggunakan timbangan digital sebanyak 25gram, kemudian dimasukkan ke dalam plastik steril yang telah diberi kode. Kemudian ditambahkan dengan media prapengkaya Buffered Pepton Water untuk bakteri Salmonella sp. dan Butterfield's Phosphate Buffered untuk bakteri Escherichia coli sebanyak $225 \mathrm{ml}$. Sampel tersebut kemudian dihomogenkan menggunakan stomacher selama kurang lebih 2 menit.

\section{Parameter Pengamatan}

Parameter pengamatan yang dilakukan pada penelitian ini yaitu pertumbuhan koloni bakteri, suhu inkubasi, waktu inkubasi dan perubahan warna media.

\section{Analisa Data}

Data yang diperoleh dari hasil penelitian diolah menggunakan Microsoft Excel 2013 dengan metode deskriptif.

\section{HASIL DAN PEMBAHASAN}

\section{Hasil}

Uji Identifikasi Bakteri Uji identifikasi bakteri Escherichia coli menggunakan metode ISO 16649-3:2015. Hasil pengujian bakteri Escherichia coli yang dapat dilihat pada tabel 1 .

\begin{tabular}{ccc}
\hline Jenis sampel & Pemeriksaan & Hasil \\
\hline Frozen Yellowfin & Eschrichia coli & Negatif \\
Frozen Mackerel & Eschrichia coli & Positif \\
Frozen Shrimp & Eschrichia coli & Negatif \\
Frozen Yellow fin & Eschrichia coli & Negatif \\
Crab Meat & Eschrichia coli & Negatif \\
Frozen octopus & Eschrichia coli & Negatif \\
Frozen Sardine & Eschrichia coli & Negatif \\
Frozen Shrimp & Eschrichia coli & Negatif \\
Frozen Mackerel & Eschrichia coli & Negatif \\
Frozen Sardine & Eschrichia coli & Negatif \\
Frozen Shrimp & Eschrichia coli & Negatif \\
Frozen Yellowfin & Eschrichia coli & Negatif \\
\hline
\end{tabular}

Hasil dari pengujian yang telah dilakukan dapat dilihat dari hasil pengujian pada media TBX. Media TBX yang positif adanya bakteri Escherichia coli memiliki warna hijau atau hijau kebiruan (Tabanella et al., 2017). Media TBX yang positif dan negatif 
terkontaminasi bakteri Escherichia coli dapat dilihat pada gambar 1 .

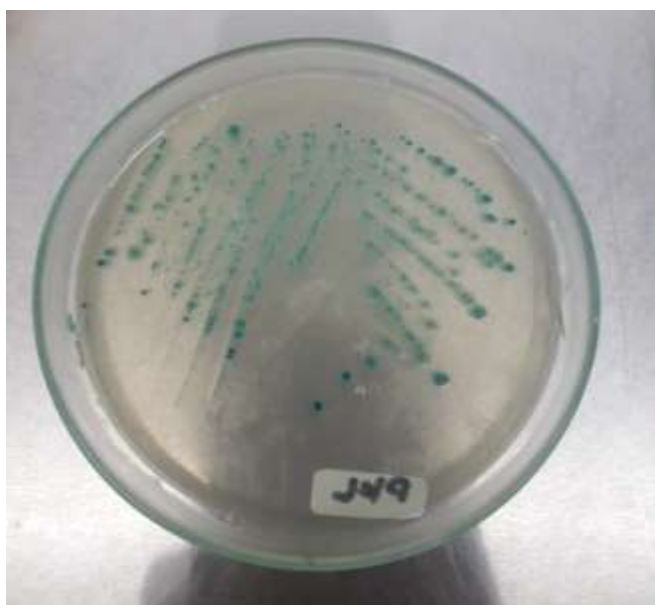

A

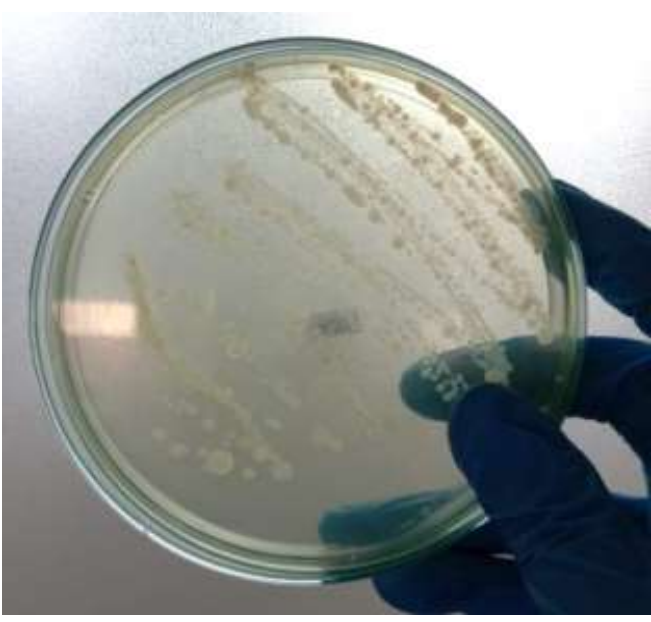

B

Gambar 1. Media TBX yang (A) positif (B) negatif terkontaminasi bakteri Escherichia coli

\section{Uji Identifikasi Bakteri Salmonella} sp.

Uji Bakteri Salmonella sp. menggunakan metode ISO 6579:2002. Hasil pengujian bakteri Salmonella sp. yang dapat dilihat pada tabel 2.

\begin{tabular}{ccc}
\hline Jenis sampel & Pemeriksaan & Hasil \\
\hline Frozen Mackerel & Salmonella sp. & Negatif \\
Frozen Mackerel & Salmonella sp. & Positif \\
Frozen Yellowfin & Salmonella sp. & Negatif \\
Frozen Yellow fin & Salmonella sp. & Negatif \\
Crab Meat & Salmonella sp. & Negatif \\
Frozen octopus & Salmonella sp. & Negatif \\
Frozen Sardine & Salmonella sp. & Negatif \\
Frozen Shrimp & Salmonella sp. & Negatif \\
Frozen Mackerel & Salmonella sp. & Negatif \\
Frozen Sardine & Salmonella sp. & Negatif \\
Frozen Shrimp & Salmonella sp. & Negatif \\
Frozen Yellow fin & Salmonella sp. & Negatif
\end{tabular}

Hasil dari pengamatan morfologi koloni yang terduga adanya bakteri Salmonella sp. dapat dilihat pada media XLD. Koloni dari media XLD kemudian ditanam pada media TSIA dan LIA untuk uji konfirmasi. Hasil dari media TSIA dan LIA yang terduga adanya bakteri Salmonella sp. kemudian bakteri tersebut diinokulasi pada media TB, urea, simmon's citrate, MRVP, laktosa, sukrosa, glukosa dan dulcitol. Hasil dari pengujian tersebut dapat dikatakan positif jika hasil uji biokimia yang dilakukan mendapatkan hasil TSIA dan LIA positif, TB negatif, urea negatif, simmon's citrate positif, MR positif, VP negatif, laktosa negatif, sukrosa negatif, glukosa positif dan dulcitol negatif (ISO 6579:2002). Hasil uji biokimia bakteri Salmonella sp. dapat dilihat pada gambar 2 

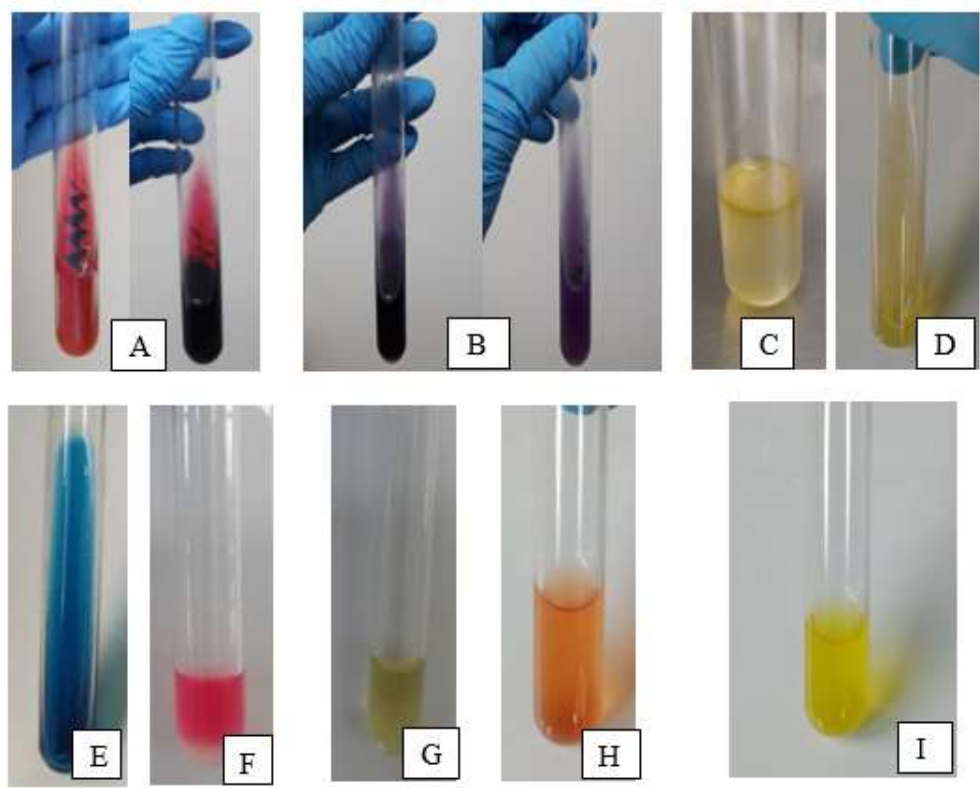

Gambar 2. Hasil uji biokimia bakteri Salmonella sp. (A) TSIA positif (B) LIA positif (C) TB negatif, (D) urea negatif, (E) simmon's citrate positif, (F) MR positif, (G) VP negatif, (H) laktosa, sukrosa, dulcitol negatif (I) glukosa positif

\section{Pembahasan}

Berdasarkan hasil penelitian yang telah dilakukan, dapat diketahui bahwa ada beberapa sampel yang dinyatakan positif Eschrichia coli dan Salmonella sp. Hal tersebut dapat diketahui dari hasil identifikasi bakteri Escherichia coli dapat diketahui berdasarkan media selektif yaitu TBX dan hasil identifikasi bakteri Salmonella sp. yang diketahui dari hasil uji biokimia yang telah dilakukan.
Media TBX merupakan media selektif yang digunakan untuk mengidentifikasi bakteri Eschrichia coli. Media Tryptone Bile Glucoronide Agar (TBX ) mengandung enzim $\quad X-\beta-D$ glucoronic acid yang berfungsi untuk membedakan bakteri coliform dengan bakteri Escherichia coli (Tabanella et al., 2017). Bakteri Eschrichia coli memiliki enzim X- $\beta$ D glucoronic acid, enzim tersebut merupakan enzim khas yang dimiliki bakteri Eschrichia coli. Kandungan enzim $X-\beta-D$ glucoronic acid dari media TBX dan bakteri Eschrichia coli akan berikatan sehingga dapat merubah warna koloni bakteri 
Escherichia coli menjadi warna biru atau hijau kebiruan (Tabanella et al., 2017).

Produk perikanan harus dinyatakan negatif dari kontaminasi bakteri Eschrichia coli agar tidak dapat menyebabkan penyakit pada manusia. Bakteri Eschericia coli dapat menyebabkan penyakit pada manusia yang disebut Entero Phatogenik Eschericia Coli (EPEC). Infeksi dari Entero Phatogenik Eschericia Coli (EPEC) ini dapat menyebabkan penyakit seperti kolera dan disentri pada anak dan orang dewasa (Bartella et al., 2011).

Hasil identifikasi bakteri Salmonella sp. dapat dilihat dari media XLD dan uji konfirmasi untuk memastikan bahwa bakteri tersebut benar adanya bakteri Salmonella sp. Media Xylose Lysine Desoxycholate (XLD) merupakan media diferensial untuk mengetahui kemungkinan bakteri Salmonella sp. (Samiea et al., 2019). Bakteri Salmonella sp. yang diduga positif dari media XLD memiliki koloni besar berwarna merah jambu (pink) dengan atau tanpa inti hitam yang mengkilat (Rabins et al., 2018). Hal tersebut dikarenakan bakteri Salmonella sp. dapat mengfermentasi xylose, mendekarboksilasi lysin dan memproduksi hidrogen sulfida dari natrium tiosulfat. Hasil fermentasi tersebut dapat merubah $\mathrm{pH}$ media XLD menjadi basa sehingga dapat merubah warna media menjadi merah jambu (pink) dan koloni berwarna hitam dihasilkan dari hidrogen sulfida (Samiea et al., 2019).

Adanya dugaan positif dari media XLD kemudian dilakukan uji konfirmasi. Adapun uji konfirmasi yang dilakukan yaitu uji TSIA, LIA, indole, urea, simmon's citrate, MRVP, laktosa, sukrosa, glukosa dan dulcitol. Uji TSIA positif ditandai dengan warna kuning pada media agar tegak dan warna merah pada media agar miring dengan atau tanpa $\mathrm{H}_{2} \mathrm{~S}$. Warna merah disebabkan oleh bakteri Salmonella sp. tidak dapat memfermentasi laktosa dan sukrosa, sedangkan warna kuning pada media tegak disebabkan oleh reaksi bakteri Salmonella sp. yang dapat mengfermentasi glukosa untuk pertumbuhannya (Anjung, 2016). Sedangkan pembentukan $\mathrm{H}_{2} \mathrm{~S}$ disebabkan oleh fermentasi $\mathrm{H}_{2}$ dan $\mathrm{CO}_{2}$ (Anjung, 2016). Uji Lysine Iron 
Agar (LIA) positif ditandai dengan tidak adanya perubahan warna atau tetap ungu dengan atau tanpa $\mathrm{H}_{2} \mathrm{~S}$. Warna ungu pada media LIA disebabkan oleh bakteri Salmonella sp. yang dapat mendekarboksilasi lysin dan menghasilkan amin kadaverin sehingga dapat merubah indikator $\mathrm{pH}$ bromcresol purple menjadi warna ungu (Haryani dkk., 2012). LIA mengandung natrium tiosulfat, yaitu suatu substrat untuk penghasil $\mathrm{H}_{2} \mathrm{~S}$, ferro sulfat menghasilkan FeS sehingga memiliki koloni berwarna hitam (Amalia, 2013).

Uji indole menggunakan media Tryptone Broth yang ditambahkan dengan reagen Covac's sebanyak $0,3 \mathrm{ml}$. Uji indole pada bakteri Salmonella sp. memiliki reaksi negatif yang ditandai dengan terbentuknya cincin berwarna kuning pada permukaan media. Hal ini disebabkan bakteri Salmonella sp. tidak dapat membentuk indol dari tryptopan sebagai sumber karbon (Sridevi and Konada, 2007). Uji urea pada bakteri Salmonella sp. memiliki reaksi negatif yang ditandai dengan tidak adanya perubahan warna pada media atau tetap berwarna kuning.
Hal tersebut dikarenakan enzim urease tidak memutuskan ikatan karbon dan nitrogen untuk membentuk ammonia dan merubah pH pada media (Mahmudah dkk., 2016). Uji simmon's citrate pada bakteri Salmonella sp. mempunyai reaksi positif yang ditandai dengan adanya perubahan warna media menjadi biru. Hal tersebut disebabkan oleh penggunaan sitrat sebagai sumber karbon untuk proses pertumbuhan dengan menghasilkan kondisi alkali (basa) (Sari dan Pratiwi, 2014). Kondisi basa yang dapat merubah warna media menjadi biru. Hal tersebut dipengaruhi oleh pemanfaatan sitrat melibatkan enzim citrat permease dan dapat memecah sitrat menjadi oksaloasetat dan asetat sehingga dapat memproduksi $\mathrm{Na}_{2} \mathrm{CO}_{3}$ serta $\mathrm{NH}_{3}$ untuk menghasilkan $\mathrm{pH}$ basa (Sari dan Pratiwi, 2014). Uji MRVP pada bakteri Salmonella memberi reaksi negatif dengan menunjukkan warna kuning pada media MRVP. Uji MR negatif dikarenakan bakteri Salmonella sp. tidak mampu memfermentasi asam yang dihasilkan dari fermentasi pada media yang mengandung glukosa 
(Puspadewi dkk, 2017). Uji VP negatif dikarenakan bakteri Salmonella sp. tidak dapat mengfermentasi 2,3-butanadiol (Puspadewi dkk., 2017). Uji laktosa, sukrosa, glukosa dan dulcitol berfungsi untuk mengetahui apakan bakteri Salmonella sp. dapat mendekarboksilase uji gula tersebut. Hasil uji laktosa dan sukrosa yaitu negatif, glukosa positif dan dulcitol negatif atau positif. Hasil uji yang dikatakan positif akan berwarrna kuning, sedangkan hasil uji yang negatif tidak menunjukan perubahan warna atau tetap berwarna orange. Perubahan warna tersebut disebakan oleh hasil fermentasi yang dapat merubah $\mathrm{pH}$ media gula-gula sehingga dapat merubah warna dari media gula-gula yang digunakan (Mindar dkk., 2017).

Produk perikanan harus dinyatakan negatif dari kontaminasi bakteri Salmonella sp. Hal tersebut dikarenakan bakteri Salmonella sp. dapat menyebabkan penyakit salmonelosis yang ditunjukkan dengan adanya gejala gastroenteritis, demam enteritika, focal infection, dan sequelae (Jay, 2005).
Kontaminasi pada produk perikanan diakibatkan adanya kontaminasi silang akibat dari keadaan yang buruk selama proses pengolahan. Faktor peningkatan kontaminasi bakteri Escherichia coli dan bakteri Salmonella sp. dapat disebabkan oleh keberadaan nutrisi dan kondisi lingkungan yang mendukung pertumbuhan bakteri tersebut (Nugraha dkk., 2012).

\section{KESIMPULAN}

Berdasarkan penelitian yang telah dilakukan dapat diketahui bahwa bakteri pathogen yang dapat mengkontaminasi produk beku perikanan adalah bakteri Escherichia coli dan bakteri Salmonella sp.

\section{DAFTAR PUSTAKA}

Alfaida, Samsurizal, M. S., dan Musdalifah Amalia, U. 2013. Optimasi Polymerase Chain Reaction (PCR) untuk Deteksi Salmonella spp. Pada Udang Segar. Tesis. Sekolah Pascasarjana Institut Pertanian Bogor. Bogor. 51 hal.

Anjung, M. U. K. 2016. Identifikasi Cemaran Salmonella sp. Dan Isolasi Bakteriofage Sebagai Biokontrol dalam Penanganan Pasca Panen Udang Vannamei (Litopennaus vannamei). Tesis. Fakultas Pertanian 
Universitas Lampung. Bandar Lampung. 75 hal.

Balai Karantina Ikan. 2011. Pedoman Analisis Resiko Hama dan Penyakit Ikan. Jakarta. Hal 1-2.

Barletta F., T. J. Ochoa, E. Mercado, J. Ruiz, L.Ecker G. Lopez, M. Mispireta, A. I. Gil, C. F. Lanata and T. G. Cleary. 2011. Quantitative Real-time Polymerase Chain Reaction for Enteropathogenic Escherichia coli: A Tool for Investigation of Asymptomatic Versus Symptomatic Infections.

Food and Agriculture Organization. (2014). The State of World Fisheries and Aquaculture. Food And Agriculture Organization Of The United Nations. Rome. 27 pg.

Garcia, S. M., And Andrew, A. R. 2010. Food security and marine capture fisheries: characteristics, trends, drivers and futureperspectives. Phil. Trans. R. Soc. B 365, 28692880pg.

Haryani Y., Chainulfifah dan Rustiana. 2012. Fermentasi Karbohidrat oleh Isolat Salmonella spp. Dari Jajanan Pinggir Jalan. Jurnal Ind. Che.Acta Vol. 3(1) : 24.

Hossain Hd. A., A. Al-Asif, Md. A. Zafar, Md T. Hossain, Md S. Alam and Md A. Islam. 2015. Marketing of fish and fishery products in Dinajpur and Livelihoods of the fish retailers. International Journal of Fisheries and Aquatic Studies. Vol. 3(1): 86-92pg.
International Standard Organitation 16649-3:2015. Microbiology Of The Chain - Horizontal Method For The Enumeration Of Beta-GlucuronidasePositive Escherichia coli Part3: Detection And Most Probable Number Tecnique Using 5-bromo-4-Chloro-3Indolyl- $\beta$-D-Glucuronide.

International Organization For Standardization, Geneva.

International Standard Organitation 6579:2002. Microbiology Of Food And Animal Feeding Stuffs - Horizontal Method For The Detection of Salmonella spp.

Jay, J. M., Loenssner, M. J. And Golden, D. A. 2005. Modern Food Microbiology. $7^{\text {th }}$ Edition. Springer Science and Business Media, Inc. New York. Pp. 619-631pg.

Ma'ruf H., Meiske S. S. Dan Audy D.W. 2017. Analisis Kandungan Formalin Dan Boraks Pada Ikan Asin Dan Tahu Dari Pasar Pinasungkulan Manado Dan Pasar Beriman Tomohon. Jurnal Mipa Unsrat, 6(2) 2428.

Mahmudah, R., Baharuddin, M., dan Sappewali, $\quad$ S. 2016. Identifikasi Isolat Bakteri Termofilik dari Sumber Air Panas Lejja, Kabupaten Soppeng. Al- kimia Jurnal Penelitian Sains Kimia, 4(1), 31-42 hal.

Mindar, Yusnaini dan Wellem H.M. 2017. Identifikasi Bakteri pada Lobster Mutiara (Panulirus ornatus) yang 
Dibudidayakan di Keramba Jaring Apung. Jurnal Media Akuatika. Vol. 2(1):300-309 hal.

Nugraha, A., Ida, B.N.G.S., dan Ketut, T.P.G. 2012. Deteksi Bakteri Salmonella spp. Dan Pengujian Kualitas Telur Ayam Buras. Indonesia Medicus Veterinus. 1(3):320329 hal.

Puspadewi, R., Putranti, A., dan Afif, A. 2017. Deteksi Staphylococcus aureus dan Salmonella pada Jajanan Sirup. Jurnal Ilmiah Manuntung, 3(1), 26-33 hal.

Rabins S. L., A Bhattacharya, VJ. A. Kumar, PX Antony, V. B. Rekha and S. V. Perumal. 2018. An Exploration On Animal And Public Health Significance Of Salmonella From Major Meat Sources In Puducherry, India. Journal Of Entomology And Zoology Studies 6(4): 1691-1699.

Samiea, S. A. E. R. A. E., Y. M. Ismaila., S. M. Fayeda., S. S. Hamedb. 2019. Evaluation Of Modified Semisolid Rappaport Vassiliadis Medium In Comparison With Conventional Media In The Isolation Of Salmonella Species From Different Samples. Benha Medical Journal Vol. 35(3): 419-428.

Sari, R dan Pratiwi, A. 2014. Cemaran Bakteri Eschericia coli dalam Beberapa Makanan Laut yang Beredar di Pasar Tradisional Kota Pontianak. Kartika Jurnal Ilmiah Farmasi, 2 (2), 14-19 hal.
Sridevi M. And Konada V.M. 2007. Bioproduction of Indole Acetic Acid by Rhizobium Strains Isolated From Root Nodules Of Green Manure Crop, Sesbania sesban (L.) Merr. Iranian Journal of Biotechnology. Vol. 5(3) : 178-182pg.

Tabanella G., C. Montanari., A. Gardini., M. Maffei., C. Prioli., And F. Gardini. 2017. Environmental Factors Affecting Escherichia coli Concentrations in Striped Venus Clam (Chamelea gallina L.) Harvested in the North Adriatic Sea. Journal of Food Protection, Vol. 80, No. 9, Pages 1429-1435. 